\title{
O DINAMISMO ECONÔMICO E PRODUTIVO DO ESTADO DE MATO GROSSO DO SUL PÓS- 2003: AS TRANSFORMAÇÕES PRODUTIVAS DAS MESORREGIÕES ${ }^{1}$
}

\author{
Fernando Rodrigo Farias \\ Universidade Federal de Mato Grosso do Sul, Campus Aquidauana \\ fernando.rodrigo@ufms.br \\ Carlos José Espíndola \\ Universidade Federal de Santa Catarina, Campus Trindade, Florianópolis \\ carlos.espindola@ufsc.br \\ Roberto César Cunha \\ Universidade Federal de Santa Catarina, Campus Trindade, Florianópolis \\ robertoujsma@hotmail.com
}

\begin{abstract}
RESUMO
O Estado do Mato Grosso do Sul apresentou, a partir de 2003, um crescimento econômico médio na ordem de $9,5 \%$ ao ano. O Produto Interno Bruto, em 2003 , somou $R \$ 21,8$ bilhões e, em 2017 , saltou para $R \$ 96,3$ bilhões. O setor de exportações, apesar dos períodos de flutuações econômicas, teve crescimento expressivo no período analisado. Em 2003, o volume das receitas das exportações somou $R \$ 497,9$ milhões e, em 2019 , atingiu $R \$ 5,2$ bilhões. Diante disso, surge a questão central: quais os fatores geoeconômicos endógenos e exógenos que contribuíram para a ocorrências dessas transformações? Nesse sentido, o artigo visa demonstrar as recentes alterações na dinâmica produtiva no estado do Mato Grosso do Sul pós-2003 e suas combinações geoeconômicas propulsoras. Metodologicamente, partiu-se de uma revisão bibliográfica acompanhada de coletas de dados nos órgãos oficiais e visando identificar as alterações na dinâmica produtiva no estado. As transformações e o reordenamento regional da matriz produtiva aconteceram de maneira concentrada em número reduzido de municípios em forma de "ilhas de desenvolvimento" nas mesorregiões. Isso ocorreu devido à estreita relação entre os investimentos estatais em setores estratégicos ligados ao movimento da economia nacional e a dinâmica do mercado externo.
\end{abstract}

Palavras-chave: Desenvolvimento econômico. Geoeconomia. Mato Grosso do Sul.

\section{THE ECONOMIC AND PRODUCTIVE DYNAMISM OF THE STATE OF MATO GROSSO DO SUL POST-2003: THE PRODUCTIVE TRANSFORMATIONS OF THE MESOREGIONS}

\begin{abstract}
Since 2003, the State of Mato Grosso do Sul has presented an average economic growth of $9.5 \%$ per year. Gross Domestic Product, in 2003, totaled R $\$ 21.8$ billion, and in 2017, it jumped to R $\$ 96.3$ billion. The export sector, despite periods of economic fluctuations, showed significant growth in the period analyzed. In 2003, the volume of export earnings totaled $R$ \$ 497.9 million and in 2019 reached $R$ \$ 5.2 billion. From all this, the central question arises: what are the endogenous and exogenous geoeconomic factors that contributed to the occurrence of these transformations? In this sense, the article aims to demonstrate the recent changes in the productive dynamics in the state of Mato Grosso do Sul after 2003 and its propelling geoeconomic combinations. Methodologically, we started with a bibliographic review accompanied by data collections in the official bodies and aiming to identify changes in the productive dynamics in the state. The transformations and the regional reorganization of the productive matrix took place in a concentrated manner in a reduced number of municipalities in the form of "development islands" in the mesoregions. This was due to the close relationship between state investments in strategic sectors linked to the movement of the national economy and the dynamics of the foreign market.
\end{abstract}

Keywords: Economic development. Geoeconomics. Mato Grosso do Sul.

\footnotetext{
${ }^{1} \mathrm{O}$ presente trabalho recebeu apoio da Universidade Federal de Mato Grosso do Sul.
} 


\title{
INTRODUÇÃO
}

As mesorregiões ${ }^{2}$ do estado do Mato Grosso do Sul apresentam variações de acordo com suas especificidades, sobretudo, por apresentar uma formação socioespacial ${ }^{3}$ com diferentes aspectos, sejam eles naturais, seja sua área de influência geoeconômica de diferentes regiões do Brasil e da América do Sul ${ }^{4}$. Essas combinações geográficas ${ }^{5}$ fazem com que seu dinamismo econômico apresente diferentes características.

Dessa maneira, Cunha e Farias (2019) assinalaram essas alterações geoeconômicas, uma vez que fazem parte de um conjunto de fatores ligados ao dinamismo cíclico econômico regional principalmente em funções de investimentos estatais de alguns programas a exemplo do Programa de Aceleração do Crescimento (PAC) e Programa de Investimento em Logística (PIL). Os principais setores que receberam investimentos nas últimas décadas foram: a indústria e o setor de infraestrutura, setores importantes para o desenvolvimento econômico passíveis de alterações na sua reorganização socioespacial. Isso posto, surge a pergunta: quais os fatores geoeconômicos endógenos e exógenos que contribuíram para essa reordenação regional no estado sul-matogrossense? Para responder a essa pergunta, levamos em consideração os principais fatores da composição econômica do estado e suas mesorregiões. Sendo assim, o objetivo central do presente artigo é analisar os principais elementos geoeconômicos que culminaram nas recentes alterações setoriais da dinâmica econômica e produtiva regional do estado de Mato Grosso do Sul.

A metodologia utilizada no texto consistiu em uma breve análise histórica da formação socioespacial do estado; estudo da composição econômica dos setores agropecuário, industrial, de serviços, inclusive a participação dos serviços públicos no percentual do Produto Interno Bruto (PIB) das mesorregiões. Também foi utilizada a análise mercadológica do setor de exportação em suas mesorregiões; a sistematização e análise dos dados do Cadastro Geral de Empregados e Desempregados (CAGED), a fim de identificar a relação de empregos formais no setor da indústria de

\begin{abstract}
${ }^{2}$ Segundo Cunha e Farias (2019, p. 145), "o IBGE apresentou uma nova divisão regional no Brasil vinculada aos processos sociais, políticos e econômicos sucedidos em território nacional desde a última versão da Divisão Regional do Brasil, publicada na década de 1990. As unidades mesorregionais e as microrregionais recebem, respectivamente, os nomes de regiões geográficas intermediárias e regiões geográficas imediatas. O recorte dessas incorpora as mudanças ocorridas no Brasil ao longo das últimas três décadas. O processo socioespacial recente de fragmentação/articulação do território brasileiro, em seus mais variados formatos, pode ser visualizado em vários estudos desenvolvidos no IBGE. O recurso metodológico utilizado na elaboração da presente Divisão Regional do Brasil valeu-se dos diferentes modelos territoriais oriundos de estudos pretéritos, articulando-os e interpretando a diversidade resultante". Uma das características naturais relevante de suas mesorregiões é o fator climático. O Mato Grosso do Sul está localizado em área de transição climática com predominância do clima tropical, que apresenta como características principais a existência de dois períodos bem definidos entre o seco e o chuvoso. Para tanto, de maneira geral a configuração climática em suas mesorregiões apresenta as seguintes características: a mesorregião Leste é do tipo úmido a subsumido (1.500 a $1750 \mathrm{~mm}$ anuais); a mesorregião do Centro-Norte apresenta como clima predominante úmido subsumido (1.500 a $1.750 \mathrm{~mm}$ anuais); a mesorregião do Pantanal Sul apresenta características climáticas entre o sumido a semiárido (800 a $1.200 \mathrm{~mm}$ anuais) em sua maior parte; em porções menores, outras características aparecem subsumido (1.200 a $1.500 \mathrm{~mm}$ anuais); a mesorregião Sudoeste apresenta clima, em sua maior porção, úmido (1.750 a 2.000
\end{abstract} $\mathrm{mm}$ anuais (BARROS, 2012).

${ }^{3}$ Segundo Espíndola; Cunha (2015) uma formação socioespacial é uma realidade concreta, que se transforma, evolui e muda com o processo histórico e geograficamente localizada. Assim, cada formação socioespacial é singular, na qual os processos gerais interagem com as características particulares e específicas, que se singularizam em função de múltiplas determinações. Por sua vez, as múltiplas determinações ampliam as possibilidades das análises, pois a realidade é fruto da relação entre os aspectos naturais e humanos. Essas relações são estabelecidas em múltiplas escalas (mundial, nacional, regional e local), e permitem compreender um determinado objeto de estudo num universo mais amplo. As múltiplas determinações de Marx aproximam-se das combinações geográficas de Cholley (1964), que afirma: "podem ser divididas em três grandes categorias: as que resultam, unicamente, da convergência de fatores físicos; aquelas, já mais complexas, que são, a um tempo, de ordem física e de ordem biológica; as mais complicadas e, por isso mesmo, mais interessantes, que resultam da interferência conjunta dos elementos físicos, dos elementos biológicos e dos elementos humanos" (CHOLLEY, 1964, p. 140).

${ }^{4}$ Essa caracterização geográfica de centralidade de localização é considerada, segundo Bourlegat (2000, p. 26), como fator facilitador, sendo Mato Grosso do Sul o mais platino dos estados brasileiros, dada a sua localização, pois que se encontra ladeado entre as bacias de rios platinos Paraguai a oeste e Paraná a leste. Essa localização funciona também como facilitador direto na relação econômica que Mato Grosso do Sul; possui não apenas com alguns dos principais estados brasileiros limítrofes ao seu território como Mato Grosso, São Paulo, Paraná, Minas Gerais e Goiás como países do continente Sul americano da Bolívia e o Paraguai.

${ }^{5}$ Conforme Cholley (1964), essas combinações podem ser de três tipos: (i) aquelas que convergem de fatores físicos (a geomorfologia, a hidrologia, etc.); (ii) aquelas de complexidade maior de ordem física e de ordem biológica (o cerrado); e (iii) as de ordem tridimensional, mais complicadas e muito mais requintadas de detalhes, de ordens físicas, biológicas e humanas (agricultura, indústria, comércio). Essas combinações geográficas ampliam as possibilidades das análises, pois a realidade é fruto da relação dialética entre os aspectos naturais e humanos.

\begin{tabular}{llllll}
\hline Caminhos de Geografia & Uberlândia-MG & v. 22, n. 79 & Fev/2021 & p. 199-218 Página 200
\end{tabular}


transformação importante no processo de alteração setorial em Mato Grosso do Sul. Além disso, foi feito o mapeamento de importantes indicadores ${ }^{6}$ que compõem a base econômica do recorte geográfico especificado. Dessa forma, o artigo é resultado de um esforço metodológico de análise geoeconômica do território de Mato Grosso do Sul tendo em vista analisar o processo de alteração da sua base produtiva nas últimas décadas.

Assim, alguns direcionamentos gerais para que pudesse proporcionar viabilidade analítica, optou-se pela via exploratória documental e bibliográfica para realizar a análise qualitativa das alterações geoeconômicas ocorridas no recorte geográfico do artigo (GIL, 1994). Operacionalmente, foram considerados os principais elementos dos setores que compõem a formação socioespacial bem como análise comparativa de suas mesorregiões dos setores primários, secundários e terciários. A revisão bibliográfica foi realizada pela análise de diferentes artigos, livros e teses que tratam de questões pertinentes à formação socioespacial de Mato Grosso do Sul, no sentido de situar o texto, considerando alguns estudos já existentes. Dentre eles, podemos citar: Mamigonian (1976), assinalou sobre a inserção da economia mato-grossense no cenário nacional; Lamoso (2011), comentou sobre as dinâmicas produtivas da economia de exportação do Mato Grosso do Sul; Bertholi (2012), tratou sobre o papel da pecuária bovina no desenvolvimento econômico sul-mato-grossense; Brum e Amorim (2016), expôs acerca dos fatores de inserção internacional de Mato Grosso do Sul: Hamada (2016), tratou dos investimentos estrangeiros diretos em Mato Grosso do Sul: Silva e Gomes (2016), trataram das áreas industriais e incentivos fiscais do estado.

O levantamento estatístico está baseado nos principais bancos de dados oficiais, tais como: relatórios estatísticos do Instituto Brasileiro de Geografia e Estatística (IBGE); relatórios técnicos do Ministério da Economia, Indústria e do Comércio Exterior (MEIC), do Banco Nacional de Desenvolvimento Econômico e Social (BNDES) e da Secretaria Estadual de Planejamento e Coordenação Geral, Desenvolvimento Econômico do Mato Grosso do Sul (SEMADE). O artigo está subdividido em quatro itens, além desta introdução e das considerações finais: (i) ocupação territorial de Mato Grosso do Sul e seu processo histórico de desenvolvimento territorial e sua vinculação com as recentes transformações geoeconômicas; (ii) a composição econômica setorial em Mato Grosso do Sul a partir dos anos 2000 em suas mesorregiões; (iii) as recentes alterações no desenvolvimento industrial em Mato Grosso do Sul; (iv) a geração de empregos formais na indústria de transformação tendo em vista a forte atração populacional nas mesorregiões de maior dinamismo neste setor o que causou alterações socioespaciais.

\section{OCUPAÇÃO TERRITORIAL E AS RECENTES TRANSFORMAÇÕES GEOECONÔMICAS EM MATO GROSSO DO SUL}

O estado de Mato Grosso do Sul com seus 79 municípios é composto por uma extensão territorial de $357.125 \mathrm{~km}^{2}$ o equivalente a $4 \%$ do território nacional e $22 \%$ da grande região Centro-Oeste. Possui uma importante especificidade territorial que é a presença do bioma Pantanal com uma área de proteção ambiental e presença de água, correspondente a $89.318 \mathrm{~km}^{2}(25 \%$ da área de extensão do estado). Essa especificidade apresenta relação conflituosa entre segmentos econômicos de diferentes interesses, principalmente no que se refere aos avanços das forças produtivas da agricultura em áreas turísticas e de preservação, assim como, relação vinculada a outras matrizes econômicas tradicionais. Pode-se afirmar que as recentes alterações geoeconômicas do Mato Grosso do Sul, com tendência à expansão de setores do agronegócio e industrial vivida a partir dos anos 2000 , com crescente inserção comercial tanto no mercado interno quanto no externo, estão vinculadas a fatores históricos socioespaciais de desenvolvimento territorial que ocorreram principalmente a partir do século XX.

Dentre essas especificidades, destacam-se: (i) a aceleração do movimento de migração interna, ocorrido a partir do século XX, que contribuiu para a expansão de importantes setores, acelerando o dinamismo econômico e aprofundando a vinculação de Mato Grosso do Sul aos diferentes centros dinâmicos da economia nacional e sul-americana; (ii) o dinamismo gerado pela construção da estrada

${ }^{6}$ Produto Interno Bruto nos setores primários; secundário e terciário, volume de exportação e importações, crescimento industrial. 
de ferro Ferronorte e da hidrovia Araguaia-Tocantins, com articulação dos projetos da Sudeco ${ }^{7}$, que contribuiu para o desenvolvimento regional a partir do século $\mathrm{XX}$, acelerando o processo de modernização da agricultura, resultando na ocupação de áreas de cerrado pela cultura da soja e outras culturas anuais, bem como com o surgimento e desenvolvimento de cidades industriais, a exemplo de Corumbá, Campo Grande, Dourados (ABREU, 2014); (iii) o movimento histórico do território do Mato Grosso do Sul está inserido aos grandes ciclos econômicos nacionais. Podemos citar o ciclo da mineração, iniciado no século XVIII que, conforme Bertholi (2006), foi responsável pela chamada "frente de entrada do planalto", recebendo influência especialmente da economia da região Sudeste do Brasil; e (iv) o processo de ação de monopólios de colonizadores ocorrido em fins do século XIX e início do século XX. Esse movimento esteve relacionado aos interesses na expansão da "marcha para o oeste", no qual fez parte do processo de interligação territorial e econômica com as áreas do centro dinâmico nacional. Segundo Abreu (2014), a região Centro-Oeste8/Mato Grosso, no qual Mato Grosso do Sul estava inserido em fins da década de 1960, incorpora-se efetivamente à dinâmica econômica nacional e também passa a cumprir o papel de absorvedora de excedentes populacionais de outras regiões, alterando, por sua vez, a sua formação social.

Outra medida econômica de âmbito nacional surgida na década de 1960, intensificada nas décadas posteriores e que possui vinculação histórica e econômica com a região Centro-Oeste, foi a implantação dos Planos de Metas a exemplo do I Plano Nacional de Desenvolvimento que ocorreu entre os anos de 1969-1973. O I PND de acordo com Rangel (1982), foi responsável pelos estímulos a novos investimentos em Siderurgia - petróleo - transportes (indústria base), que acelerou o desenvolvimento do mercado interno com a implantação e ampliação do sistema de transportes para ligação e integração regional brasileira. Esse processo proporcionou a necessidade de incorporar novas áreas de expansão, a exemplo do Centro-Oeste. Posteriormente, nas décadas seguintes, outros fatos históricos foram essenciais para que a Região Centro-Oeste e Mato Grosso do Sul se inserisse efetivamente como parte do centro dinâmico nacional em setores específicos, a exemplo do setor do agronegócio, como a criação da Empresa Brasileira de Pesquisa Agropecuária (EMBRAPA), como destacou Delgado (1985), que foi um dos fatores responsáveis pela viabilização da expansão produtiva de culturas anuais, como a soja, milho e algodão em áreas do Cerrado.

É importante destacar, ao mesmo tempo, dois projetos de intervenção estatal implantados na região Centro-Oeste, entre 1989 e 1993, com investimentos do mercado externo com recursos oriundos do Banco Mundial que funcionaram como alternativa de financiamento da base produtiva em decorrência da escassez de crédito rural da crise econômica da década de 1980 que atendeu à expansão da nova fronteira agrícola: (i) o Plano Nacional de Desenvolvimento Rural (PNDR), com investimentos de mais de U\$\$ 300 milhões; e (ii) o Plano Nacional de Desenvolvimento Agroindustrial (PNDA), tendo a Região Centro-Oeste como receptáculo da maior parte do total investido nos respectivos programas. Esses projetos foram implantados estrategicamente para alavancar o processo de desenvolvimento do novo polo de produção da agricultura brasileira. Seus investimentos ocorreram em sequência estratégica: enquanto o primeiro financiou a abertura e inversão de culturas anuais na chamada "nova fronteira agrícola" do Brasil central, o segundo financiou a compra de máquinas e equipamentos, e a implantação de agroindústrias, empresas multinacionais agroquímicas, que receberam grandes volumes de recursos, a exemplo de setores ligados à fabricação e venda de herbicidas, acaricidas, fungicidas, produtos veterinários (antibióticos para aves) e para a fabricação de fertilizantes (FONSECA; GONÇALVES,1995).

Dessa maneira, esses elementos históricos endógenos contribuíram para o surgimento de setores dinâmicos em Mato Grosso do Sul e região Centro-Oeste. Exemplos desses setores são de papel e celulose, e frigoríficos, que possuem vinculação ao processo de surgimento do complexo agroindustrial de grandes "unidades geoeconômicas" que, se encontravam em pleno

\footnotetext{
${ }^{7}$ De acordo com Abreu (2014, p. 11-13), a Superintendência de Desenvolvimento do Centro-Oeste (SUDECO) cumpriu função de planejamento e intervenção estatal que nortearam o avanço do capital e a integração nacional. Os limites de atuação delimitaram aos limites territoriais dos atuais estados de Mato Grosso e Mato Grosso do Sul. A superintendência fez parte do processo de "racionalização e das políticas regionais para os anos oitenta", cujo foco era desenvolver "estudos para a formulação de políticas públicas de Desenvolvimento implementadas pelos governos federal e estaduais".

8 De acordo com Abreu (2014), as políticas para a integração do território nacional corresponderam a uma ação rápida e combinada para simultaneamente, completar a ocupação do território, incorporando o Centro-Oeste e a "ilha" amazônica; modernizar e expandir a economia nacional, articulando-a à internacional; estender o controle do Estado a todas as atividades e a todos os lugares.
} 
desenvolvimento nas diferentes porções territoriais do país. Conforme Mamigonian (1976), a região Sul do Mato Grosso (atual Mato Grosso do Sul) desempenhava papel principalmente como área de criação de gado para posterior engorda em fazendas da região Sudeste. Com o desenvolvimento do setor logístico, facilitou o transporte de gado magro para serem engordados e abatidos em frigoríficos da região Sudeste onde se encontrava o grande mercado consumidor.

A "marcha para o oeste" e a expansão da nova fronteira agrícola para a produção de novas culturas transferiram capital financeiro do centro dinâmico para novas áreas do Centro-Oeste, o que gerou novas cadeias produtivas. O surgimento e a expansão desse conjunto de fatores econômicos resultaram no processo de desenvolvimento de abertura e consolidação dos mercados internos e externos da região Centro-Oeste. A relação século XX (aceleração do processo de formação socioespacial) e século XXI (desenvolvimento de setores secundários e terciários) produziu novo dinamismo econômico e territorial em Mato Grosso do Sul, vinculados aos efeitos do desenvolvimento dos ciclos econômicos anteriores especialmente aos setores industriais acoplados ao desenvolvimento dos agronegócios que produziram alterações geoeconômicas nas diferentes regiões do Estado.

\section{A GEOECONOMIA SETORIAL EM MATO GROSSO DO SUL A PARTIR DOS ANOS 2000}

Entende-se que, para efetuar uma análise do recente dinamismo econômico setorial de Mato Grosso do Sul, é necessário considerar alguns dos principais elementos socioespaciais em curso: (i) há no estado, conforme IBGE (2019), áreas de dispersão e concentração populacional: (ii) Mato Grosso do Sul é formado por áreas geoeconômicas de forte dinamismo econômico e áreas que se encontram em desenvolvimento; (iii) o estado possui regiões com boa infraestrutura produtiva e áreas com carência infraestrutural. Entretanto, mesmo que o PIB tenha aumentado significativamente a partir dos anos 2000, conforme se observa na figura 1, a disparidade e concentração econômica nas mesorregiões são fatores característicos.

Figura 1 - Total do Produto Interno Bruto das Mesorregiões de Mato Grosso do Sul de 2002 a 2017 (R \$ bilhões).

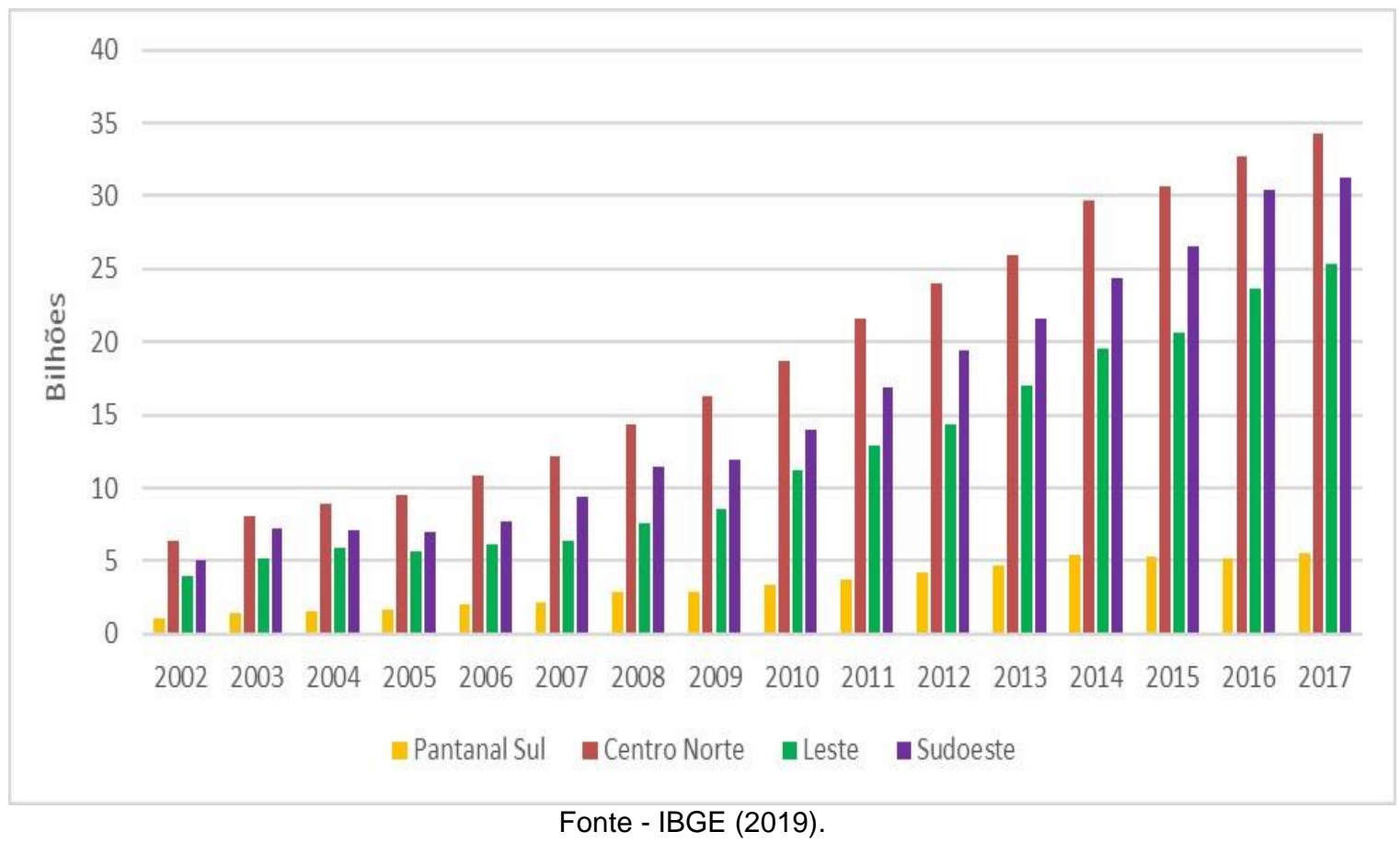

Assim, a figura 1 demonstra o movimento de expansão do dinamismo econômico em relação ao PIB nas mesorregiões de Mato Grosso do Sul, em que, na relação 2002 a 2017, a mesorregião Pantanal Sul apresentou crescimento de $376,58 \%$, o Centro-Norte, 408,07\%, Leste 503,53\% e a mesorregião

\begin{tabular}{|c|c|}
\hline Caminhos de Geografia & Uberlândia-MG \\
\hline
\end{tabular}


Sudoeste, 506,53\%. O total do PIB das quatro mesorregiões de Mato Grosso do Sul em 2002 somava $\mathrm{R} \$ 16,4$ bilhões e, em 2017, saltou para $\mathrm{R} \$ 96,3$ bilhões (IBGE, 2019). Também, a Figura 2 mostra a distribuição em percentuais do PIB nas mesorregiões de Mato Grosso do Sul. Contudo, mesmo com os dados demonstrando a divisão do protagonismo quantitativo entre as mesorregiões Centro-Norte Leste e Sudoeste de Mato Grosso do Sul, é preciso considerar a existência de fatores de "desequilíbrios regionais", no qual estão expostos na base concreta. Dentre os fatores, está a forte concentração da produção de riquezas em um número limitado de municípios que exercem a função de polo regional. Esses desequilíbrios são considerados como um importante gargalo a ser superado.

Figura 2 - Produto Interno Bruto Por mesorregião de Mato Grosso do Sul em $2017^{9}$.

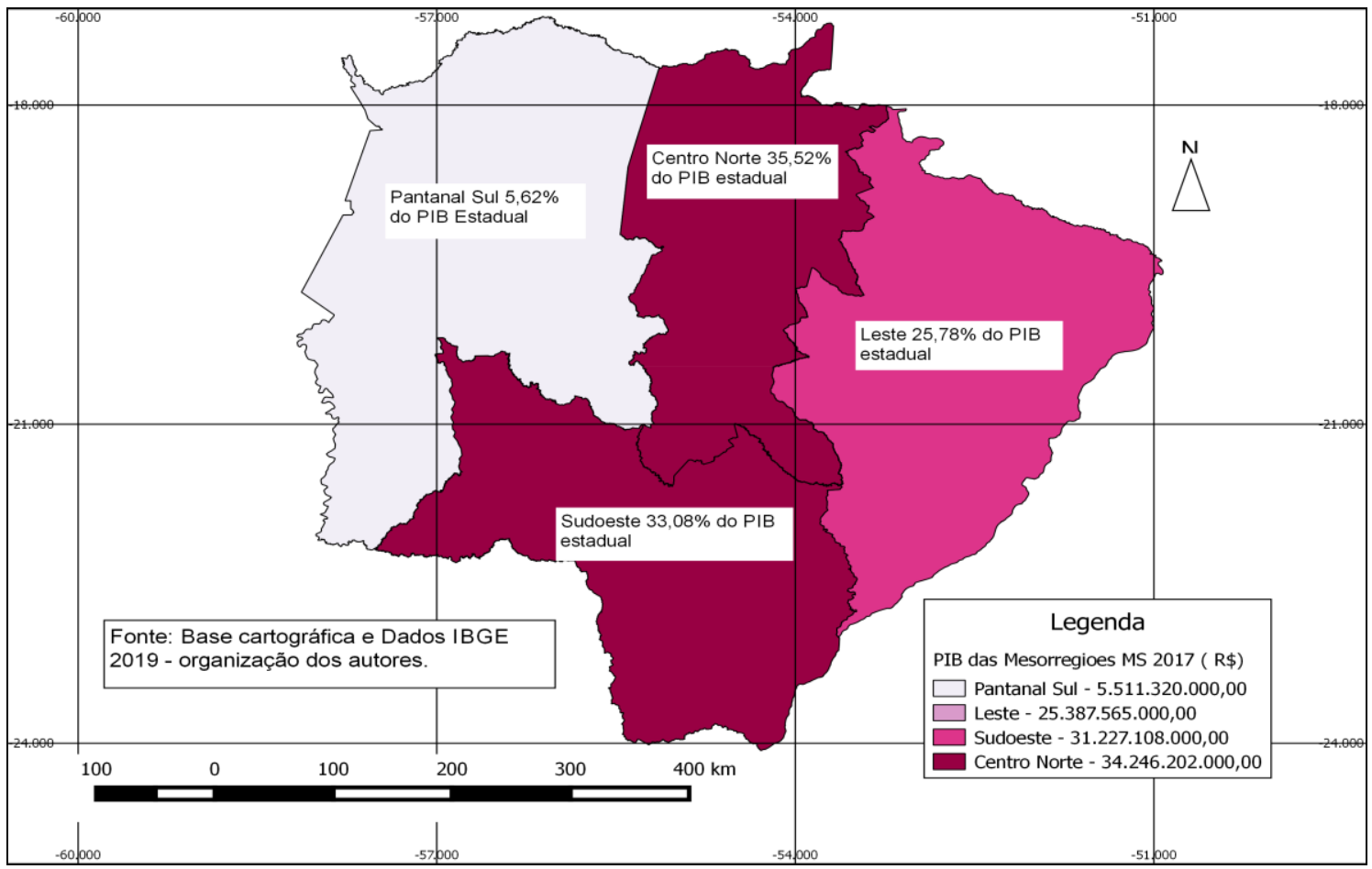

Fonte - IBGE (2019).

Nota-se, por meio da análise quantitativa do PIB, a existência de uma hierarquia no dinamismo econômico de alguns municípios que estão diluídos entre as mesorregiões. É exemplo a mesorregião Centro-Norte, que possui como principal município a capital Campo Grande que, segundo IBGE (2019) a capital concentra 32,2\% da população estadual (2019) e $27,69 \%$ do PIB estadual (estimativa disponível de 2017). A concentração econômica entre alguns municípios é uma característica estrutural de Mato Grosso do Sul. De acordo com a Secretaria de Meio Ambiente e Desenvolvimento Econômico (SEMADE), utilizando a estimativa do Instituto Brasileiro de Geografia e Estatística do ano de 2015 , assinala que os seis municípios de maior economia responderam por $58,24 \%$ da riqueza gerada no estado. Porém, os 54 municípios menores economicamente contribuíram com apenas $18,26 \%$ do PIB do estado e detêm $25,3 \%$ da população residente de Mato Grosso do Sul, e os $62,5 \%$ do seu contingente populacional residem em apenas onze municípios ${ }^{10}$. A mesorregião Sudoeste, que possui a segunda maior participação no total do PIB estadual, com $33,08 \%$ do total do Estado (figura 2), abrange um total de 38 municípios, sete deles - Dourados, Ponta Porã, Naviraí, Maracaju, Rio Brilhante, Caarapó e Ivinhema - concentram $51,6 \%$ do total do PIB da mesorregião. Entretanto, o

\footnotetext{
${ }^{9}$ Os dados do PIB das mesorregiões só estão disponíveis na base de dados do IBGE até o ano de 2017.

10 De acordo com IBGE (2019), a soma total da população residente nesses onze municípios atingiu 1.724 .509 habitantes, e 885.711 habitantes $(51,36 \%)$, desse total, residem na capital, Campo Grande.
}

$\begin{array}{lllll}\text { Caminhos de Geografia } \quad \text { Uberlândia-MG } & \text { v. 22, n. } 79 & \text { Fev/2021 } & \text { p. 199-218 Página } 204\end{array}$


município de Dourados responde sozinho por 25,8\% desse total. Esses municípios apresentam forte dinamismo no setor agropecuário, com significativa presença de plantas industriais ligadas à soja, álcool e ao setor de frigoríficos. A região, chamada "região de planejamento da grande Dourados", que, segundo SEMADE (2015), abrange os municípios de Caarapó, Deodápolis, Douradina, Dourados, Fátima do Sul, Glória de Dourados, Itaporã, Jateí, Maracaju, Rio Brilhante e Vicentina, concentram $32 \%$ do total das plantas industriais instaladas e em funcionamento do estado de Mato Grosso do Sul; o município de Dourados possui 597 indústrias (SEMADE, 2015).

A mesorregião Leste de Mato Grosso do Sul também apresenta forte concentração financeira em poucos municípios. Composta por dezoito municípios; Três Lagoas, Selviria, Paranaíba, Nova Andradina, Costa Rica, Chapadão do Sul e Água Clara concentram $73,14 \%$ do total do PIB dessa região. Três Lagoas responde sozinho por 39\% do total (IBGE, 2019). A expansão do PIB da mesorregião Leste está diretamente ligada ao movimento de instalação de plantas industriais do setor de papel e celulose que ocorreu a partir de 2009, sobretudo no município de Três Lagoas, onde grandes empresas do setor (exemplo: Fibria Celulose, International Paper do Brasil e Eldorado Brasil) se instalaram (ANDRADE, 2016).

É importante levar em conta que o movimento expansivo do setor industrial da mesorregião Leste possui vinculação histórica que remete ao ano de 1988 quando a International Paper do Brasil se instalou no município de Três Lagoas. Essa empresa realizou diversas pesquisas nas áreas de modelo de gestão florestal, manejo de florestas, desenvolvimento operacional, bem como a capacitação de mão de obra para o setor (ANDRADE, 2016). O ano de 2006 é um marco importante para a mesorregião Leste de Mato Grosso do Sul pelo fato de coincidir tanto com o início dos projetos de investimentos de grandes indústrias de papel e celulose quanto com o princípio de investimentos em infra-estruturas logísticas no estado, a exemplo da pavimentação da BR 158 entre Três Lagoas e o município de Selviria, Aparecida do Taboado, representando um importante elo logístico regional.

Conforme destaca Andrade (2016), o movimento cíclico expansivo do setor industrial da mesorregião Leste, que possui como município polo Três Lagoas, é fruto de uma série de combinações e vantagens que resultaram num rápido processo de alteração econômica e espacial naquela mesorregião. Pode-se destacar o fato de a microrregião de Três Lagoas ${ }^{11}$ possuir um polo de geração de energia hidroelétrica e termelétrica. Para mais, localizar-se às margens do Rio Paraná, utilizando o potencial hidroviário do Paraná/Tietê, que faz divisa com o Estado de São Paulo estabelecendo relações comerciais, servida por importantes vias rodoviárias como a BR $262,{ }^{12}$ que atravessa o estado de Mato Grosso do Sul de Leste a Oeste (Três Lagoas a Corumbá), com acesso ao estado de São Paulo (Porto de Santos importante porto de escoamento da produção industrial). É servida, também, pela malha ferroviária Malha Oeste S.A. sob concessão da América Latina Logística (ALL), que liga Corumbá a Bauru, no estado de São Paulo, considerado um importante "corredor de distribuição da celulose". É importante, ainda, como vantagem da Mesorregião Leste e Mato Grosso do Sul em geral o acesso ao gasoduto Bolívia-Brasil ${ }^{13}$, essencial fator energético para o setor industrial.

O processo de desenvolvimento industrial da mesorregião Leste proporcionou uma série de elementos de efeito multiplicador na microrregião. Em 2011, o município de Três Lagoas cadastrou mais de mil pequenas empresas no perfil "Super Simples", que passaram a desenvolver serviços de demanda do setor industrial em ascensão (SEMADE, 2015). Até 2015, havia em operação um total de 54 setores industriais de variados ramos, como o têxtil, calçadista, cereais, refrigeração e celulose. No mesmo ano, o município de Três Lagoas atingiu o segundo maior PIB do Estado atrás apenas da capital Campo Grande, atingindo um total de onze mil postos de trabalho direto no setor industrial (ANDRADE, 2016). Ainda segundo Andrade (2016), o município de Três Lagoas passou a responder por $28 \%$ da produção nacional de celulose vegetal.

\footnotetext{
${ }^{11}$ Formada pelos municípios de Águas Claras; Brasilândia; Ribas do Rio Pardo; Santa Rita do Rio Pardo e Três Lagoas.

12 Através da BR 262 é possível fácil acesso à BR 163 que atravessa o Estado de Mato Grosso do Sul de Sul a Norte, estabelecendo ligação tanto com a Região Sul do Brasil (absorvedor de demandas comerciais e acesso ao Porto de Paranaguá) quanto com regiões produtivas do estado vizinho de Mato Grosso.
} 
Para uma análise qualitativa do PIB nas mesorregiões de Mato Grosso do Sul, consideramos indispensável destacar um conjunto de características de âmbito natural, socioespacial e de localização geográfica no qual suas mesorregiões estabelecem diferentes relações econômicas de maneira inter-regional com diferentes centros dinâmicos do Brasil e países da América do Sul. Apesar de ter sofrido significativas alterações quantitativas no total do PIB do estado como mostra a figura 3 , considera-se que ainda apresenta grande potencial para expansão em decorrência de haver desenvolvimento concentrado em número reduzido de municípios, e também por apresentar uma dinâmica econômica em transição com alteração gradativa de seus setores da matriz produtiva.

Figura 3 - Evolução do PIB das mesorregiões de Mato Grosso do Sul de 2002 a 2017 (R\$ bilhões).

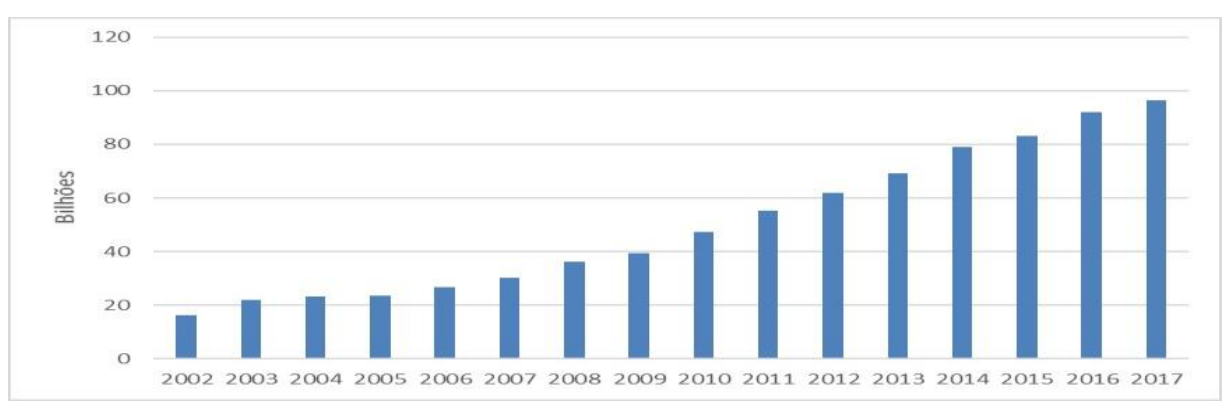

Fonte - IBGE, 2019.

Conforme a figura 3, é a partir de 2007 que o total do PIB estadual sofre significativo processo de expansão, fruto de movimentos endógenos de crescimento da demanda interna e mercado externo, ambos ligados aos setores agropecuário e industrial, do qual Mato Grosso do Sul passou a participar com maior intensidade nas últimas décadas. Esse movimento demandou e estimulou o crescimento de uma série de atividades econômicas dos setores que compõem o PIB, a exemplo dos setores industriais, agropecuário e de serviços.

\section{O DESENVOLVIMENTO INDUSTRIAL EM MATO GROSSO DO SUL A PARTIR DA DÉCADA DE 2000}

O desenvolvimento do setor industrial em Mato Grosso do Sul é considerado "tardio", pois que foi uma das últimas regiões do Brasil a desenvolver esse setor. Seu dinamismo embrionário está vinculado a fatos históricos ocorridos principalmente a partir da década de 1970, conforme apontam Brum e Amorim (2016). Para tanto, um desses fatores está ligado ao fato de que, a partir da década de 1970, o seu território passou a ser considerado como "um importante expoente da agroindústria nacional" (BRUM; AMORIM, 2016). No entendimento dos autores, a partir de 1970, houve um processo de cooperação de investimentos internacionais no estado. Com apoio do governo brasileiro que, em nível nacional, possuía interesses em intensificar investimentos para a modernizar a matriz produtiva na Região Centro-Oeste, considerada importante para as demandas internas do centro dinâmico nacional. Esse sistema de cooperação deu origem a programas de desenvolvimento regional, como o Programa de Cooperação Nipo-Brasil para o desenvolvimento do Cerrado (PRODECER), que recebeu US\$ 60 milhões entre investimentos dos governos brasileiro e japonês, que visava ao aumento da produtividade de alimentos.

Além disso, outros programas fizeram parte desse processo embrionário do desenvolvimento industrial em Mato Grosso do Sul, entre eles: o Programa de Desenvolvimento do Cerrado (POLOCENTRO); o Programa de Desenvolvimento da Grande Dourados (PRODEGRAN); e o Programa para o Desenvolvimento do Pantanal (PRODEPAN). Embora esses programas não tenham atuado como protagonistas, eles funcionaram como auxiliares ao desenvolvimento industrial em Mato Grosso do Sul (BRUM; AMORIM, 2016). O setor industrial vem se alterando mesmo considerando

$\begin{array}{lllll}\text { Caminhos de Geografia } \quad \text { Uberlândia-MG } & \text { v. 22, n. } 79 & \text { Fev/2021 } & \text { p. 199-218 Página } 206\end{array}$


que o seu desenvolvimento possui características de "ilhas de desenvolvimento". É notável o crescimento da participação do setor industrial em regiões específicas, proporcionando alterações na dinâmica geoeconômica regional. $O$ volume de produtos industrializados é indicativo de uma dinâmica expansiva do setor que teve um aumento de $3.241 \%$ na relação 2000 a 2015 , ou seja, $R \$$ 49,05 milhões em 2000 para $R \$ 1,6$ bilhão em 2015. Entretanto, essa expansão está restrita a um número limitado de municípios onde o setor tem uma participação expressiva no PIB.

O número de municípios com seus respectivos setores mais importantes na sua composição econômica, conforme Tabela1, possui a forte participação do setor agropecuário, com $49,37 \%$ dos municípios, seguido do setor de serviços e serviços públicos. O setor industrial possui apenas 7,59\% dos municípios como o mais importante em suas economias, mas está relacionado ao fato de que, desse total, quatro municípios - Aparecida do Taboado (32,48\% do seu PIB); Bataguassu (37,15\%); Selviria (83,96\%); Três Lagoas $(61,51 \%)$ - pertencem à mesorregião Leste de Mato Grosso. O restante do desenvolvimento industrial encontra-se em regiões específicas de acordo com as diferentes aptidões geoeconômicas.

Tabela1 - Composição do PIB dos municípios 2017.

\begin{tabular}{l|c|c}
\hline \multicolumn{2}{c}{ Setores no total do PIB municipal No de municípios } & 7,59 \\
\hline Setor industrial & 6 & 8,86 \\
\hline Setor de serviços públicos & 7 & 34,18 \\
\hline Setor de serviços & 27 & 49,37 \\
\hline Setor agropecuário & 39 & $\mathbf{1 0 0}$ \\
\hline
\end{tabular}

Fonte - IBGE, 2019.

A figura 4 compara o setor industrial em relação aos outros setores quanto à participação do PIB entre as mesorregiões. Confirma o destaque para a mesorregião Leste com forte presença de indústrias de papel e celulose. A mesorregião Sudoeste apresenta características diferentes quanto ao perfil industrial, embora não tenha apresentado quantitativamente uma evolução expressiva do setor industrial no PIB total, há presença forte do setor agroindustrial sobretudo ligados aos setores de alimentos e processamento de grãos, como a cana de açúcar e frigoríficos.

Figura 4 - Percentual de participação do setor industrial em Mato Grosso do Sul por mesorregião 2002-2017.

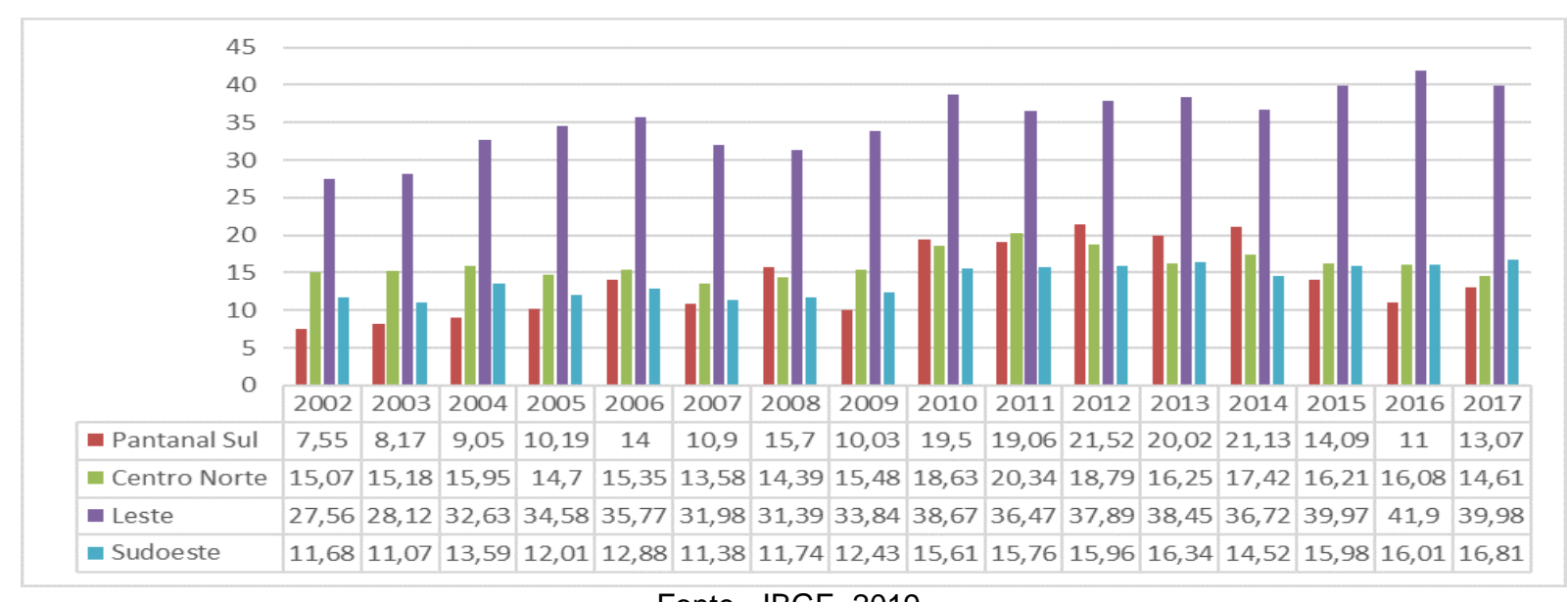

Fonte - IBGE, 2019.

$\begin{array}{lllll}\text { Caminhos de Geografia } \quad \text { Uberlândia-MG } & \text { v. 22, n. 79 } & \text { Fev/2021 } & \text { p. 199-218 Página } 207\end{array}$


Nota-se, com base na figura 4, que o processo de expansão do setor industrial de Mato Grosso do Sul possui forte vinculação com as recentes modificações da dinâmica comercial que o estado vem sofrendo nas últimas décadas:

a) Por razões endógenas (ação estatal na economia) - de acordo com Silva e Gomes (2016), após os anos 2000, o Mato Grosso do Sul foi beneficiado pelo processo de retomada de políticas governamentais de fomento à industrialização marcado por medida de incentivos fiscais do governo estadual, a exemplo da Lei n 93/200114, responsável pela criação do Programa Estadual de Fomento à Industrialização, ao Trabalho, ao Emprego e à Renda. Sua proximidade territorial com São Paulo, bem como com outras regiões dinâmicas do país "promoveu uma industrialização com uma peculiaridade, cujas plantas industriais são oriundas em sua maioria (40\%) do estado de São Paulo". As políticas de incentivos industrial beneficiaram uma série de setores industriais como, por exemplo, o de processamento de soja; bovinocultura; avícola; suinocultura; beneficiamento de leite e derivados; processamento de couro; setor têxtil; indústria de construção; indústria de açúcar e álcool; e a indústria de madeira e móveis.

b) Por motivos exógenos - crescimento da demanda internacional, que intensificou sua relação com o mercado externo. A dinâmica comercial de Mato Grosso do Sul ligada à inserção internacional (exportação/importação ${ }^{15}$ ) principalmente através de suas agroindústrias acopladas ao setor do seu agronegócio possui papel relevante no que concerne às modificações geoeconômicas em suas mesorregiões.

O processo de inserção comercial da economia estadual no mercado externo possui relação a fatos ocorridos, principalmente a partir de 1990, quando a relação comercial internacional se intensificou. Influenciado pelos efeitos da abertura comercial brasileira, o Mato Grosso do Sul recebeu grande número de empresas multinacionais com forte vinculação à rede mundial do comércio. Empresas, como a Fibria (papel e celulose), JBS (frigoríficos), Archer Daniels Midland (grãos), passaram a atuar em regiões estratégicas do estado, fazendo parte da estrutura de formação do capital (BRUM; AMORIM, 2016).

Esse novo dinamismo foi responsável pelo processo de alteração do perfil produtivo exportado (Tabela 2). O movimento de alteração do perfil dos produtos exportados pela indústria de Mato Grosso do Sul, relativamente ao período de 2003 a 2019, vem ocorrendo em virtude do desenvolvimento e da expansão da matriz produtiva do estado. Ao mesmo tempo em que se nota a expansão do setor exportador ligado a um setor industrial em desenvolvimento, é possível constatar a predominância de produtos com menor grau de incorporação tecnológica no produto. Se em 2003, $72,28 \%$ dos produtos exportados eram do tipo intermediários, esse percentual atingiu $80,31 \%$ em 2019, sendo os produtos de bens de consumo exportados semimanufaturados os que apresentaram queda; em 2003, representavam 27,69\% e, em 2019, passam a representar $19,47 \%$ do total exportado.

\footnotetext{
${ }^{14}$ Ocorreu via benefício ou incentivos fiscais concedidos às indústrias que se instalaram ou realizaram ampliações de suas infraestruturas. Os principais incentivos foram de até $67 \%$ do ICMS por quinze anos prorrogáveis pelo mesmo tempo. Possibilidade de dispensa do pagamento do ICMS incidente sobre as entradas interestaduais ou sobre importações de máquinas e equipamentos destinados ao ativo fixo da empresa. Deferimento do ICMS incidente sobre as importações de matérias-primas. Estado e municípios concederam doações de áreas em núcleos industriais; terraplanagem; isenção de Imposto Territorial Urbano (IPTU) e Imposto sobre Serviços (ISS), além de incentivos para capacitação de mão de obra (ANDRADE, 2016, P. 110).

${ }^{15}$ Os principais produtos importados pelo estado de Mato Grosso do Sul são: o gás natural (61\%) da Bolívia fruto do Gasoduto Bolívia-Brasil Gasbol; cloreto de Potássio, Cótodo de cobre, Fio de Poliester ( $9,1 \%$ das importações), este vem principalmente da China (BRUM; AMORIM, 2016, p. 30).
}

\begin{tabular}{|c|c|}
\hline Caminhos de Geografia & Uberlândia-MG \\
\hline
\end{tabular}


Tabela 2 - Perfil da produção exportada de Mato Grosso do Sul 2003-2019.

\begin{tabular}{|c|c|c|c|c|c|c|c|}
\hline Ano & Total & $\begin{array}{c}\text { Bens de } \\
\text { Capital-N1 } \\
16\end{array}$ & $\%$ & $\begin{array}{l}\text { Bens Intermediários } \\
\qquad N 2^{17}\end{array}$ & $\%$ & $\begin{array}{c}\text { Bens de } \\
\text { consumo N3 }\end{array}$ & $\%$ \\
\hline 2003 & 497898846 & 167795 & 0,03 & 359878251 & 72,28 & 137852800 & 27,69 \\
\hline 2004 & 643324678 & 343930 & 0,05 & 442633661 & 68,80 & 200347087 & 31,14 \\
\hline 2005 & 1145110583 & 4156134 & 0,36 & 715069922 & 62,45 & 425829639 & 37,19 \\
\hline 2006 & 1003978158 & 4186217 & 0,42 & 796818628 & 79,37 & 202201646 & 20,14 \\
\hline 2007 & 1296208010 & 373557 & 0,03 & 995532009 & 76,80 & 298339335 & 23,02 \\
\hline 2008 & 2091477854 & 913090 & 0,04 & 1405097048 & 67,18 & 677752140 & 32,41 \\
\hline 2009 & 1889606719 & 5448028 & 0,29 & 1241705617 & 65,71 & 635876274 & 33,65 \\
\hline 2010 & 2888971566 & 6001236 & 0,21 & 2112380541 & 73,12 & 766288974 & 26,52 \\
\hline 2011 & 3839516997 & 9151124 & 0,24 & 3046721184 & 79,35 & 771719444 & 20,10 \\
\hline 2012 & 4173130569 & 7764396 & 0,19 & 3295849779 & 78,98 & 866541577 & 20,76 \\
\hline 2013 & 5224916593 & 9356451 & 0,18 & 4187225792 & 80,14 & 1026911427 & 19,65 \\
\hline 2014 & 5214623904 & 9846902 & 0,19 & 4065575044 & 77,96 & 1137440210 & 21,81 \\
\hline 2015 & 4731553588 & 15111886 & 0,32 & 3876396706 & 81,93 & 838536771 & 17,72 \\
\hline 2016 & 4071045681 & 11064211 & 0,27 & 3293131271 & 80,89 & 765805844 & 18,81 \\
\hline 2017 & 4785068453 & 8231152 & 0,17 & 3856731404 & 80,60 & 919201491 & 19,21 \\
\hline 2018 & 5759297040 & 9913933 & 0,17 & 4895321494 & 85,00 & 852950232 & 14,81 \\
\hline 2019 & 5243374006 & 10503136 & 0,20 & 4210797669 & 80,31 & 1020694887 & 19,47 \\
\hline
\end{tabular}

Fonte - Ministério da Economia, Indústria e do Comércio Exterior - MEIC, (2019).

Embora tenha ocorrido expansão dos produtos intermediários, é possível observar quantitativamente o lento processo de incorporação tecnológica no setor produtivo industrial processador, ficando restrito a exportações de produtos básicos nas quais apresentam menor envolvimento tecnológico ${ }^{19}$.

\footnotetext{
${ }^{16}$ De acordo com MEIC (2019), os produtos exportados pertencem a essa linha os Bens de capital (exceto equipamentos de transporte), Equipamentos de transporte industrial.

${ }^{17}$ Conforme o MEIC (2019), os produtos exportados pertencem a essa linha os insumos industriais elaborados; alimentos e bebidas básicos, destinados principalmente à indústria, Insumos industriais básicos, peças e acessórios para bens de capital, peças para equipamentos de transporte.

18 Os produtos exportados pertencentes a este grupo referem-se a alimentos e bebidas elaborados, destinados principalmente ao consumo doméstico, Bens de consumo não duráveis, Bens de consumo semiduráveis, Automóveis para passageiros, Equipamentos de transporte não industrial (MEIC, 2019).

${ }^{19}$ Classificação dos produtos exportados pela economia brasileira quanto ao nível tecnológico: Produtos da indústria de transformação de média-baixa tecnologia: Coque, produtos derivados do petróleo e biocombustíveis; Embarcações navais; Metalurgia; Produtos de borracha e de material plástico; Produtos de metal, exceto máquinas e equipamentos; Produtos minerais não metálicos. Produtos da indústria de transformação de média-alta tecnologia: Máquinas e equipamentos:

Caminhos de Geografia

Uberlândia-MG $\quad$ v. 22, n. 79

Fev/2021

p. $199-218$

Página 209
} 
Tanto que houve aumento do percentual exportado de produtos intermediários e diminuição do percentual de bens de capital exportado (Tabela 2). Segundo MEIC (2019), quanto à classificação do nível tecnológico incorporado na produção exportada, é necessário ressaltar que as exportações do estado, em 2019, 36,97\%, foram em pasta química para madeira, considerado produto intermediário. Embora o produto exportado de ambos os produtos possua classificação na indústria de transformação como baixo nível de acabamento, são setores que agregam alta tecnologia incorporada e uma série de setores que fazem parte de sua dinâmica produtiva.

O aumento do volume de receitas de produtos exportados, conforme figura 5, é um dos indicadores da expansão das estruturas industriais no estado. Parte desse crescimento se deve principalmente em decorrência da ação do Estado, que passou a investir significativos volumes financeiros no setor industrial na região, e no aumento da demanda de consumo por produtos industrializados por parte do mercado interno dos países em desenvolvimento. O crescimento desse volume exportado de produtos industrializados foi puxado principalmente pelos setores de papel celulose, frigorífico, processamento de grãos, mineração e sucroenergéticas (LAMOSO, 2016). Conquanto tenha havido aumento gradativo do volume financeiro das exportações, nota-se que a balança comercial do estado possui histórico negativo na relação exportações/importações. O período analisado de 2000 a 2019 (figura 5) mostra que apenas a partir de 2013 é que o volume das exportações ultrapassa o volume financeiro das importações.

Figura 5 - Receitas das exportações/importações de Mato Grosso do Sul 2000-2018 (US\$ bilhões).

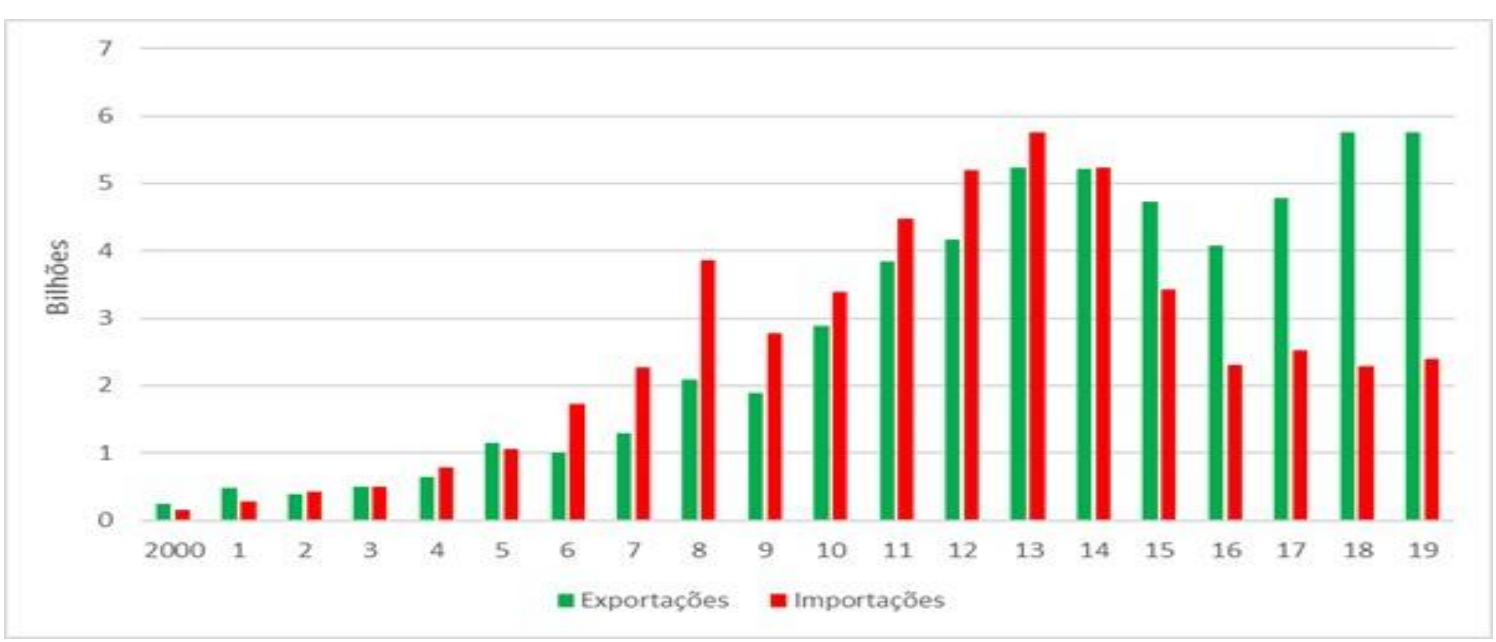

Fonte - Ministério da Economia, Indústria e do Comércio Exterior - MEIC (2019).

O recente dinamismo industrial de Mato Grosso do Sul é um dos responsáveis pela evolução do volume de industrializados exportados. Na medida em que setores da indústria se alteraram, passaram a demandar uma série de produtos básicos e de serviços importados. A exemplo: a importação energética, especialmente gás natural (utilizado para as termoelétricas) vindo da Bolívia, em 2016 representou 54,92\% das importações do Estado. Além disso, conforme o MEIC (2019), o

Máquinas, aparelhos e materiais elétricos; Produtos químicos; Veículos automotores, reboques e carrocerias; Veículos ferroviários e equipamentos de transporte. Produtos da indústria de transformação de baixa tecnologia: Outras manufaturas; Artigos do vestuário e acessórios; Bebidas; Celulose, papel e produtos de papel; Couros, artefatos de couro, artigos para viagem e calçados; Equipamentos de informática; produtos eletrônicos e ópticos; Impressão e reprodução de gravações; Madeira e seus produtos; Móveis; Produtos alimentícios; Produtos do fumo; Produtos têxteis. Produtos da indústria de transformação de alta tecnologia: Aeronaves; Equipamentos de informática, produtos eletrônicos e ópticos; Produtos farmoquímicos e farmacêuticos (MEIC, 2019).

$\begin{array}{lllll}\text { Caminhos de Geografia } \quad \text { Uberlândia-MG } & \text { v. 22, n. } 79 & \text { Fev/2021 } & \text { p. 199-218 Página } 210\end{array}$


volume financeiro das importações de produtos da indústria química e indústria têxtil passou a ser demandado em razão do processo de expansão da indústria de transformação nos seus principais polos industriais. Assim, a partir de 2013, os efeitos dos investimentos em plantas industriais, ocorrido de forma mais significativa em 2006, começam a apresentar maior peso na balança comercial do estado.

A atual composição produtiva do mercado exportador está vinculada a alguns fatos históricos ocorridos em décadas anteriores que alteraram a geografia econômica do estado, produzindo a atual configuração produtiva. Os efeitos gerados pelos investimentos externo (décadas de 1970), integração nacional do Centro-Oeste às regiões dinâmicas do país (décadas de 1970/1980), abertura comercial e a chegada de grandes empresas multinacionais (década de 1990), e os resultados do ciclo expansivo endógeno/exógeno com aplicação de políticas públicas de investimento e estruturantes (a partir do ano de 2000), desencadearam um processo de alteração da sua matriz produtiva ligado ao mercado interno e externo de Mato Grosso do Sul. Esse conjunto de fatos ligados ao movimento cíclico da economia Sul-mato-grossense, os principais produtos de exportação (figura 6) permitem lançar duas constatações:

Figura 6 - Os cinco principais produtos exportados por Mato Grosso do Sul 2003- 2019 (US\$) ${ }^{20}$.

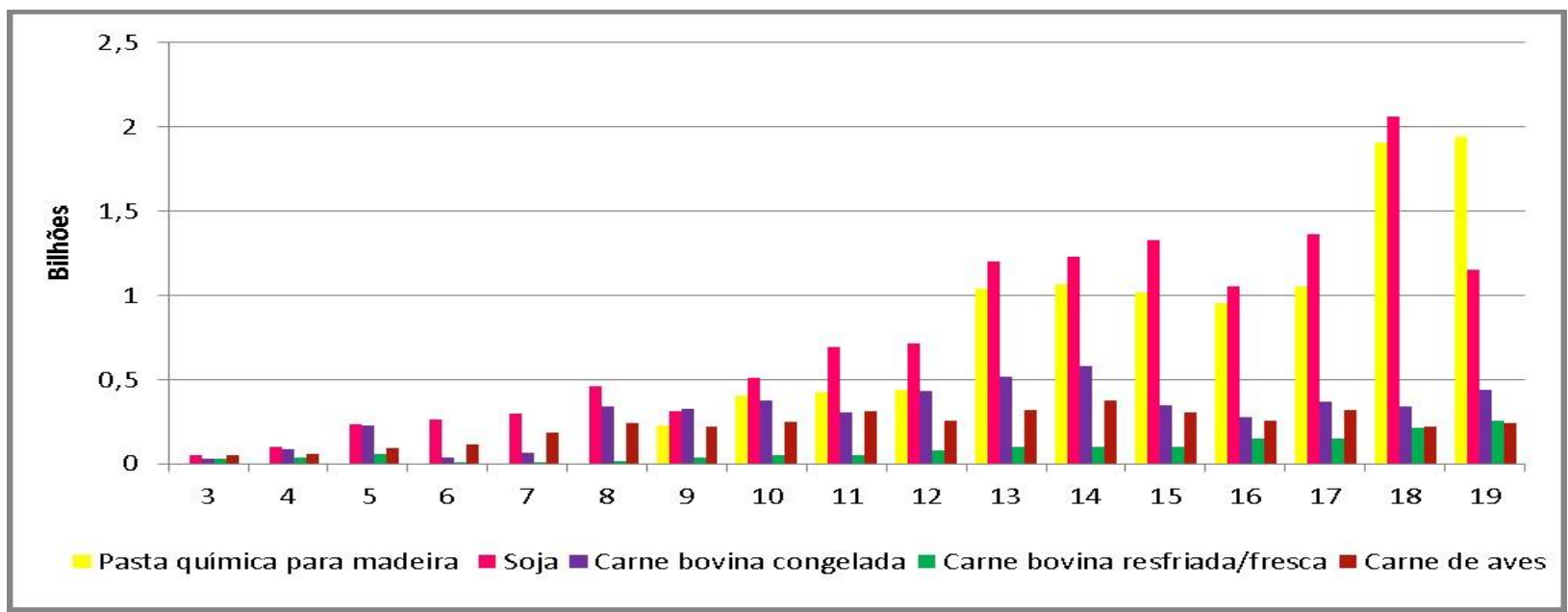

Fonte - Ministério da Economia, Indústria e do Comércio Exterior - MEIC (2019).

1- Os cinco principais grupos de produtos exportados (pasta química para madeira, soja, carne bovina congelada, carne bovina fresca ou refrigerada e carne de aves) apresentaram crescimento constante na maioria do período e concentraram $76,71 \%$ do volume financeiro exportado pelo Estado em 2019. Afinal, são produtos que fazem parte daqueles grupos de produtos agroalimentares cuja demanda mundial vem crescendo.

2- Alguns setores tradicionais da pauta de exportações do estado perderam espaço para outros setores que apresentaram crescimento mais robusto. O setor de mineração, as exportações de minério de ferro, de acordo com o MEIC (2019), em 2011, representaram o auge de sua movimentação financeira no mercado exportador, chegaram a representar $14,96 \%$ do volume financeiro exportado, em 2019 representaram apenas 2,69\% do volume financeiro exportado (figura 7).

O setor econômico da mineração faz parte daqueles importantes setores tradicionais do estado, o qual foi um dos primeiros setores a se desenvolver e existe a presença de políticas de incentivos de redução de tributação de ICMS afinal, é um setor importante tanto economicamente quanto na geração de empregos a Secretaria de Estado de Meio Ambiente, Desenvolvimento Econômico, Produção e Agricultura Familiar (SEMAGRO, 2017). De acordo com a figura 7, o setor apresentou crescente participação das exportações até 2011 com pequena oscilação em 2007 e 2009. Para tanto, a partir de 2014, o setor apresentou significativa queda no volume financeiro exportado, houve queda de $70,48 \%$ na relação 2014 e 2015.

${ }^{20}$ Representaram 76,71\% do volume financeiro exportado em 2019 - US $\$ 3,7$ bilhões.

$\begin{array}{lllll}\text { Caminhos de Geografia } \quad \text { Uberlândia-MG } & \text { v. 22, n. 79 } & \text { Fev/2021 } & \text { p. 199-218 Página } 211\end{array}$


Figura 7 - Principais produtos de exportação de origem mineral em Mato Grosso do Sul 2003- 2019 (US\$).

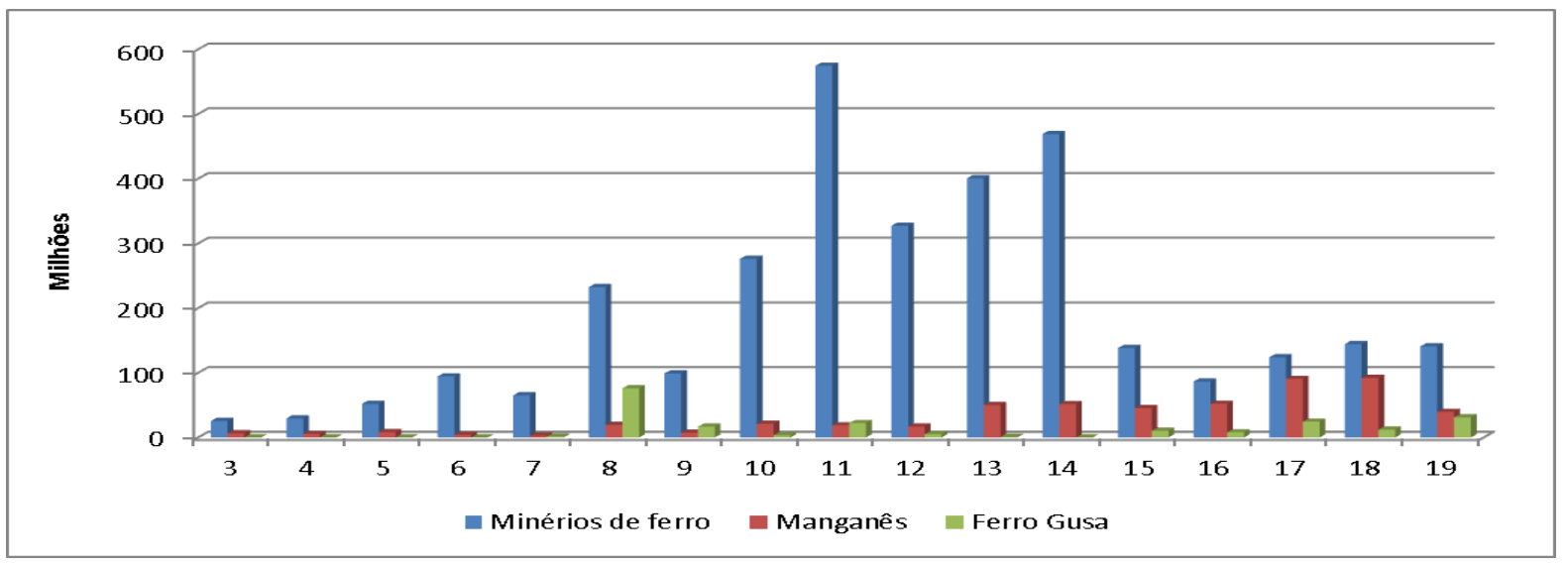

Fonte - Ministério da Economia, Indústria e do Comércio Exterior - MEIC (2019).

Os movimentos de mercado indicam algumas razões para esse movimento oscilatório do mercado exportador dos produtos de origem mineral (figura 7). A presença de crise econômica vivida por importantes países parceiros, a exemplo da Argentina, que, ao lado da China, está entre os maiores compradores de minério de ferro. Além disso, está a queda os preços das commodities no mercado internacional.

Não obstante, alguns setores importantes, que nas últimas décadas apresentaram crescimento significativo em virtude do ciclo expansivo vivido pelo, país a partir de 2003, acabaram perdendo espaço na pauta das exportações em período recente. É o caso das exportações de carne de suínos que apresentou significativas oscilações entre crescimento e queda conforme mostra a figura 8.

Figura 8 - Exportações de carne suína em Mato Grosso do Sul 2003-2019 (toneladas).

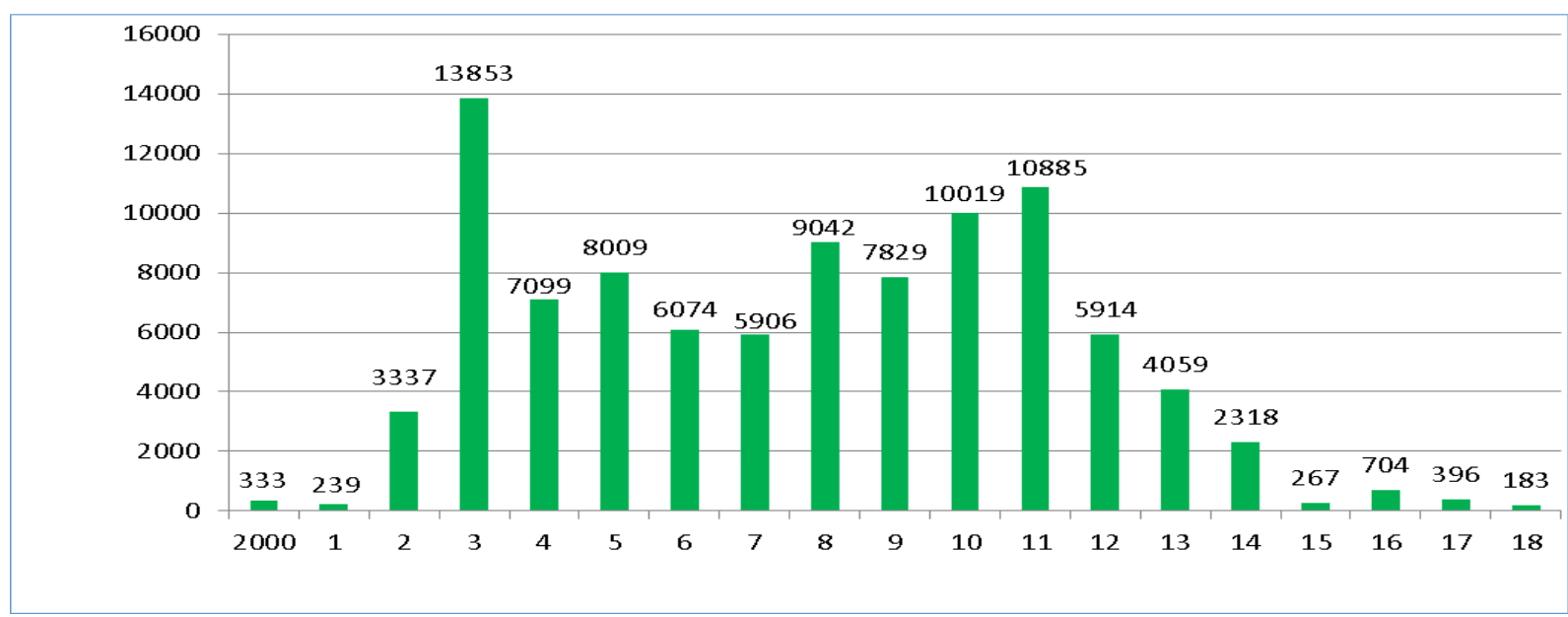

Fonte - Ministério da Economia, Indústria e do Comércio Exterior - MEIC (2019).

A figura 8 demonstra o movimento oscilatório das exportações de carne suína. O período de maior perda de força se deu a partir de 2011. Nos períodos recentes, de acordo com Associação Brasileira de Proteína Animal (ABPA 2019), apresentaram queda de 5,4\%. Os embarques para os países asiáticos apresentaram queda de $21 \%$ em 2017. Dentre os fatores de desaceleração das exportações de carne suínas, está o aumento da produção doméstica dos países asiáticos, como Hong Kong, que é o principal importador da carne suína de Mato Grosso do Sul. Outro fator que explica essa queda nas vendas externas é o aumento da produção e exportação de suínos em outras unidades da federação, sobretudo, o estado de Santa Catarina ${ }^{21}$. O setor exportador de carne suína está entre os

\footnotetext{
${ }^{21}$ Informações extraídas de entrevistas realizadas em pesquisa de campo na Associação Catarinense de Criadores de Suínos em dezembro de 2017.
}

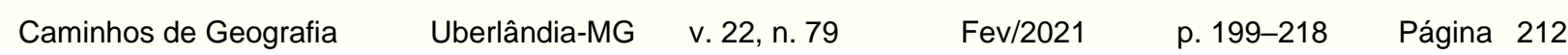


setores em desenvolvimento no Estado de Mato Grosso do Sul. Sua estrutura agrária e produtiva vinculada historicamente a outros setores, a exemplo da pecuária bovina, passa a partir da década de 1990 a perceber a expansão da produção de culturas anuais a exemplo da soja, milho, cana e algodão. Recentemente tem iniciado um movimento de desenvolvimento em regiões específicas de outras cadeias produtivas como a de suínos, piscicultura. De acordo com IBGE (2019), a mesorregião do Estado com maior percentual de cabeças de gado suíno pertence a mesorregião Sudoeste, que abrange $54,71 \%$ do rebanho do estado. A referida mesorregião possui como principal polo o município de Dourados, que é o principal exportador de carne suína do estado. Em Dourados encontram-se instalados grandes complexos agroindustriais processadores, como a JBS/Seara e, em paralelo a esses setores, encontram-se instalados outros complexos agroindustriais, a exemplo da cooperativa agroindustrial paranaense Coamo, que recentemente fez investimento em planta industrial em Dourados.

Outros polos importantes no processamento de carne suína são a capital Campo Grande com plantas industriais, dentre elas a JBS e São Gabriel do Oeste com a Cooperativa Central Aurora de Santa Catarina. Essa última, de acordo com SEMADE (2019), possui a segunda maior planta industrial de processamento de carne suína. Para tanto, mesmo que tenha havido desaceleração em alguns setores da cadeia produtiva processadora de carne a exemplo da de suínos, têm ocorrido uma série de investimentos de expansão dos setores como a da Coamo em Dourados, Aurora Alimentos no município de São Gabriel do Oeste mesorregião Centro-Norte. Há um grande potencial de expansão no mercado interno tanto para o próprio estado de Mato Grosso, quanto para abastecer o mercado interno de outras regiões do Brasil.

O mercado externo de Mato Grosso do Sul vem se desenvolvendo por várias razões, já mencionadas anteriormente no texto; um dos fatores fundamentais que precisa ser considerado é a forte demanda externa pelos produtos de exportação do estado por países em desenvolvimento, como, por exemplo, o continente asiático, demonstrado no Tabela 3.

Tabela 3 - Principais destinos das exportações do estado do Mato Grosso do Sul.

\begin{tabular}{|c|c|c|}
\hline Países importadores & US\$ FOB & Part. \% \\
\hline China & 1429552048 & 35,11 \\
\hline Itália & 215904434 & 5,30 \\
\hline Países Baixos (Holanda) & 211553669 & 5,20 \\
\hline Argentina & 165304211 & 4,06 \\
\hline Rússia & 157534849 & 3,87 \\
\hline Hong Kong & 132733521 & 3,26 \\
\hline Arábia Saudita & 111831291 & 2,75 \\
\hline Chile & 105425385 & 2,59 \\
\hline Japão & 102031977 & 2,51 \\
\hline Tailândia & 96212374 & 2,36 \\
\hline Vietnã & 94719046 & 2,33 \\
\hline Irã & 87850161 & 2,16 \\
\hline Egito & 87625722 & 2,15 \\
\hline Estados Unidos & 86682267 & 2,13 \\
\hline Coreia do Sul & 85039513 & 2,09 \\
\hline Indonésia & 67397355 & 1,66 \\
\hline Emirados Árabes Unidos & 66901134 & 1,64 \\
\hline Taiwan & 60939605 & 1,50 \\
\hline Malásia & 58971776 & 1,45 \\
\hline Espanha & 50215552 & 1,23 \\
\hline Demais países ${ }^{22}$ & 302135296 & 14,66 \\
\hline $\begin{array}{c}\text { Total } \\
\end{array}$ & 4071270346 & 100,00 \\
\hline
\end{tabular}

22 Dentre os principais destaques estão Argélia (0,95\%), Bangladesh (0,90\%), Paraguai $(0,83 \%)$, Venezuela $(0,79 \%)$, França $(0,76 \%)$, Bolívia $(0,75 \%)$, Iraque $(0,65 \%)$, Alemanha $(0,55 \%)$, Israel $(0,54 \%)$, Paquistão $(0,53 \%)$.

\begin{tabular}{|c|c|}
\hline Caminhos de Geografia & Uberlândia-MG \\
\hline
\end{tabular}


A ascensão dos países emergentes ao final do século $X X$ e início do século $X X I$, destaque para a China, foi responsável pela alteração da geografia econômica mundial conforme afirmaram Espósito e Cruz (2016). A partir da década de 1990, ainda no governo Fernando Henrique Cardoso, ocorreram acordos bilaterais entre os países emergentes, como Brasil e China como parte estratégica de política externa que visava criar "um regionalismo na América Latina". Dessa forma, conforme o Tabela 3, o percentual do destino das exportações de Mato Grosso do Sul para países emergentes soma 74,96\% sendo que para os países desenvolvidos representam 25,08\%. Ademais, com as mudanças de econômicas em associação com transformações dos sistemas produtivos, houve significativa modificação na estrutura de empregos no estado do Mato Grosso do Sul.

\section{A GERAÇÃO DE EMPREGOS FORMAIS NA INDÚSTRIA DE TRANSFORMAÇÃO EM MATO GROSSO DO SUL}

O processo de geração de empregos formais na indústria de transformação é relevante, uma vez que esse setor faz parte do movimento das recentes alterações da matriz produtiva Mato Grosso do Sul. O setor da indústria de transformação possui importância significativa nas mesorregiões do Estado na medida em que essas estruturas produtivas passam a demandar por uma série de serviços inerentes à indústria de transformação. A indústria de transformação vem apresentando seu dinamismo atrelado ao aumento da demanda produtiva, seja para o mercado interno, seja para o mercado externo. De acordo com CAGED (2018), no ano de 2018, esse setor em Mato Grosso do Sul foi responsável por $18,78 \%$ dos empregos formais diretos. A geração de empregos formais a partir de 2003 apresentou seu dinamismo vinculado ao momento cíclico no qual o Brasil passou a viver. Com forte aumento da demanda internacional pelos principais produtos exportáveis, aumento dos investimentos internos, ampliação de programas de acesso ao crédito para o sistema produtivo, tudo isso fez com que se desenvolvesse demanda por empregos formais em todas as regiões brasileiras.

A geração de empregos formais em Mato Grosso do Sul no setor da indústria de transformação obedeceu à tendência afirmada anteriormente. Vinculado ao dinamismo econômico do centro dinâmico nacional e tendo o mercado interno como importante fonte para expansão do PIB, a estrutura de empregos passou, a partir de 2014, a apresentar saldo negativo na geração de empregos formais como mostra a figura 9.

Figura 9 - Geração de empregos formais na indústria de transformação em Mato Grosso do Sul 2007 a 2018.

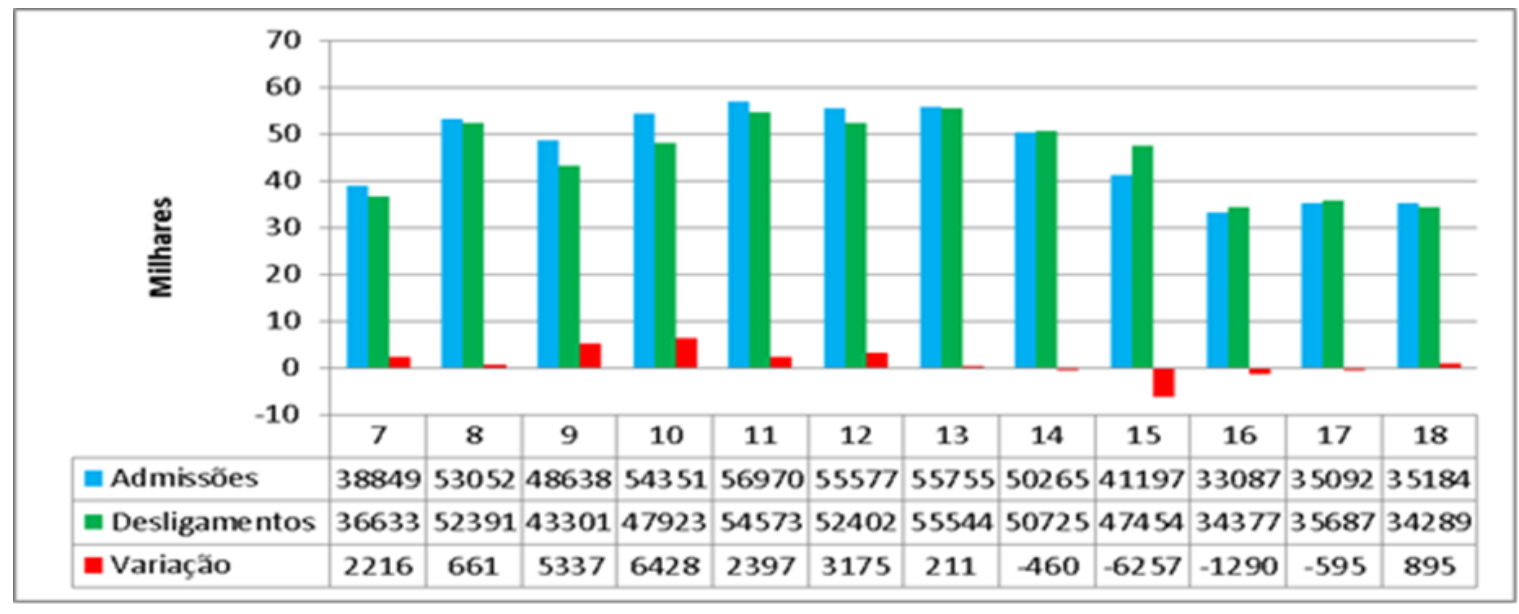

Cadastro geral de Empregados e desempregados - CAGED 2018.

Mesmo considerando o movimento cíclico de saldo negativo na geração de empregos vivido pelo Brasil e Mato Grosso do Sul a partir de 2014, nota-se um setor da indústria de transformação vinculado a outros setores com aumento no saldo positivo e responsável por significativo percentual na geração de empregos formais direto conforme mostra a Tabela 4.

$\begin{array}{lllll}\text { Caminhos de Geografia } \quad \text { Uberlândia-MG } & \text { v. 22, n. } 79 & \text { Fev/2021 } & \text { p. 199-218 Página } 214\end{array}$


Tabela 4 - Geração de empregos formais em Mato Grosso do Sul por setor em 2018.

\begin{tabular}{l|c|c}
\hline \multicolumn{1}{c}{ Setor } & 2337 & 0,46 \\
\hline Extração mineral & 2963 & 0,59 \\
\hline Adm. Pública & 6678 & 1,32 \\
\hline Serviços de utilidade pública & 22066 & 4,37 \\
\hline Construção civil & $\mathbf{6 9 3 1 1}$ & $\mathbf{1 3 , 7 3}$ \\
\hline Agropecuária & $\mathbf{9 4 7 9 3}$ & $\mathbf{1 8 , 7 8}$ \\
\hline Indústria de transformação & 123740 & $\mathbf{2 4 , 5 1}$ \\
\hline Comércio & 182959 & $\mathbf{1 0 0}$ \\
\hline Serviços Total & $\mathbf{5 0 4 8 4 7}$ & \\
\hline \multicolumn{2}{c|}{ Fonte - Cadastro geral de Empregados e desempregados - CAGED (2018). }
\end{tabular}

Em se tratando dos principais municípios em suas microrregiões nas regiões industrializadas do Estado, constata-se peso significativo da indústria de transformação na geração de empregos formais (Tabela 5).

Tabela 5 - Número de empregos formais existentes na indústria de transformação nas microrregiões de Mato Grosso do Sul em 2018.

\begin{tabular}{l|c|c}
\hline \multicolumn{1}{c}{ Microrregião } & $\mathbf{2 2 1 7 8}$ & $\mathbf{2 3 , 4 0}$ \\
\hline Microrregião de Campo Grande & $\mathbf{1 2 3 2 8}$ & $\mathbf{1 3 , 0 1}$ \\
\hline Microrregião de Três Lagoas & 1015 & 1,07 \\
\hline Microrregião de Corumbá & 1596 & 1,68 \\
\hline Microrregião de Aquidauana & 3656 & 3,86 \\
\hline Microrregião de São Gabriel do Oeste & 3931 & 4,15 \\
\hline Microrregião do Chapadão do Sul & 6822 & 7,20 \\
\hline Microrregião da Parnaíba & 7017 & 7,40 \\
\hline Microrregião Nova Andradina & 1215 & 1,28 \\
\hline Microrregião de Bodoquena & $\mathbf{2 2 7 0 3}$ & $\mathbf{2 3 , 9 5}$ \\
\hline Microrregião de Dourados & $\mathbf{1 2 3 3 2}$ & $\mathbf{1 3 , 0 1}$ \\
\hline Microrregião de Iguatemi & & \\
\hline
\end{tabular}

Fonte - Cadastro geral de Empregados e desempregados - CAGED (2018).

Levando em conta a relação existente entre os setores agropecuário, indústria de transformação, comércio e de serviços, podemos afirmar que estabelecem uma importante inter-relação na geração de empregos formais conforme destacamos na Tabela 6. Embora estatisticamente o comércio e os serviços representaram, em 2018, em Mato Grosso do Sul 60,75\% dos empregos formais, é fundamental considerar que a sua existência está vinculada ao desenvolvimento dos setores da indústria de transformação e o setor agropecuário fortemente dinamizado. A análise central do objeto de estudos do presente artigo está pautada nas recentes alterações geoeconômicas da matriz produtiva nas suas mesorregiões de Mato Grosso do Sul. É importante destacar o papel do agronegócio e da indústria de transformação nesse processo.

$\begin{array}{lllll}\text { Caminhos de Geografia } \quad \text { Uberlândia-MG } & \text { v. 22, n. } 79 & \text { Fev/2021 } & \text { p. 199-218 Página } 215\end{array}$ 
Tabela 6 - Número de empregos formais existente na indústria de transformação nos principais municípios de cada microrregião em 2018 (unidades).

\begin{tabular}{|c|c|c|}
\hline $\begin{array}{l}\text { Principal município por } \\
\text { microrregião }\end{array}$ & $\begin{array}{l}\text { Número de Empregos formais } \\
\text { existentes na indústria de } \\
\text { transformação em } 2018\end{array}$ & \% em relação ao Estado. \\
\hline Campo Grande & 17682 & 18,65 \\
\hline Três Lagoas & 10.337 & 10,90 \\
\hline Corumbá & 974 & 1,03 \\
\hline Aquidauana & 621 & 0,66 \\
\hline São Gabriel do Oeste & 2487 & 2,62 \\
\hline Chapadão do Sul & 1494 & 1,58 \\
\hline Aparecida do Taboado & 3865 & 4,08 \\
\hline Nova Andradina & 3313 & 3,49 \\
\hline Guia Lopes da Laguna & 390 & 0,41 \\
\hline Dourados & 10580 & 11,16 \\
\hline Angélica & 4981 & 5,25 \\
\hline Total em relação ao Estado & 56724 & 59,84 \\
\hline
\end{tabular}

Fonte - Cadastro geral de Empregados e desempregados - CAGED (2018).

De acordo com as Tabelas 5 e 6, é perceptível que nos municípios em que o setor da indústria de transformação sofreu alterações apresentam esse setor como relevante no percentual de geração de empregos formais. Tanto que, conforme Tabela 6 , os principais municípios de cada uma das microrregiões do Estado espalhados em suas mesorregiões representaram, em 2018, 59,84\% de todos os empregos formais na indústria de transformação no estado do Mato Grosso do Sul.

\section{CONSIDERAÇÕES FINAIS}

De acordo com a análise do objeto de estudo desenvolvido no presente texto, pode- se considerar que o dinamismo de alteração da matriz produtiva do Estado de Mato Grosso do Sul é resultado de dois conjuntos de fatores: (i) fruto do processo da expansão e amadurecimento da estrutura produtiva de um conjunto de fatos históricos ocorridos entre os séculos $X X$ e XXI; (ii) resultado da reorganização da estrutura produtiva com investimentos estatais nos setores cruciais da matriz produtiva (indústria - infraestrutura/logística).

O Estado de Mato Grosso do Sul apresenta em sua formação socioespacial a existência de uma hierarquia, em que o PIB de alguns municípios concentra a maior parcela da riqueza produzida. Embora tenha ocorrido desenvolvimento industrial significativo a partir de 2003, o setor é o mais importante apenas para seis municípios do estado, sendo a mesorregião Leste com amplo destaque no setor em relação às outras mesorregiões. O desenvolvimento industrial em Mato Grosso do Sul é responsável por parte significativa do dinamismo de alteração da matriz produtiva naqueles municípios que concentram a maior parte de seu desenvolvimento. Esse dinamismo possui razões endógenas (aumento da demanda interna) e exógenas (aumento da relação externa de Mato Grosso do Sul com o mundo).

Apesar de o mercado exportador de Mato Grosso do Sul ter apresentado período de expansão, especialmente a partir de meados da década de 2000, foi demonstrado um aumento gradativo do percentual exportado de bens intermediários (nível 2) no que diz respeito às exportações de bens de consumo (nível 3) com maior índice tecnológico incorporado. O superávit comercial dessas exportações relativamente às importações só se tornou positivo a partir de 2013. Sendo a hipótese considerada no presente texto que é a partir desse ano que os efeitos dos investimentos em infraestrutura e indústria ocorridos em especial a partir de 2005 atingem maior capacidade de

$\begin{array}{lllll}\text { Caminhos de Geografia } & \text { Uberlândia-MG } & \text { v. 22, n. } 79 & \text { Fev/2021 } & \text { p. 199-218 Página } 216\end{array}$


maturação. O volume financeiro exportado de Mato Grosso do Sul em 2019 apresentou concentração, sendo os cinco principais produtos exportados - pasta química para madeira, soja, carne bovina e aves - representando $76,71 \%$ do total exportado. Já outros setores tradicionais da pauta de exportação a exemplo do setor de mineração vêm perdendo espaço no total exportado em detrimento da expansão de outros setores, como a celulose, frigoríficos (bovinos, aves e suínos) e derivados de soja. A maior parte do mercado externo de Mato Grosso do Sul (74,96\%) tem como compradores países emergentes e 25,08\% países desenvolvidos. Portanto, o desempenho econômico e as transformações produtivas sul-mato-grossenses são frutos de combinações geográficas.

\section{REFERÊNCIAS BIBLIOGRÁFICAS}

ABPA. Associação Brasileira de Proteína Animal. Relatório anual das exportações de carne brasileira. São Paulo, 2019. Disponível em: http://abpa-br.org/mercados/. Acesso em: 15 mar. 2020.

ABREU, S. de. Planejamento governamental: a Sudeco no espaço mato-grossense: contexto, propósitos e contradições. Contexto, propósitos e contradições. 2014. 382 f. Tese (Doutorado) Curso de Geografia, Ufgd, Dourados, 2014.

ANDRADE, V. de S. O setor de celulose e o papel de Três Lagoas Ms: Inserção no mercado internacional e transformações logísticas. In: LAMOSO, L. P. (org.). Relações Internacionais de Mato Grosso do Sul: comércio, investimentos e fronteira. Curitiba: Ithala, 2016. p. 93-118.

BARROS, V. M. Atlas geográfico de Mato Grosso do Sul e seus municípios. Campo Grande: Oeste, 2012. $11 \mathrm{p}$.

BERTHOLI, A. O lugar da pecuária na formação sócio-espacial sul-mato-grossense. 2006. 227 f. Dissertação (Mestrado) - Curso de Geografia, Universidade de Federal de Santa Catarina, Florianópolis, 2006.

BERTHOLI, A. Peculiaridades do desenvolvimento no Mato Grosso do Sul: formação sócioespacial e pecuarização. 2012. 191 f. Tese (Doutorado) - Curso de Geografia, Universidade de Federal de Santa Catarina, Florianópolis, 2012.

BOURLEGAT, C. A. Le. Mato Grosso do Sul e Campo Grande: Articulações Espaço-temporais. 2000. 421 f. Tese (Doutorado) - Curso de Geografia, Universidade Estadual Paulista Faculdade de Ciências e Tecnologia, Presidente Prudente, 2000.

BRUM, A. K. de; AMORIM, G. P. A inserção internacional de Mato Grosso do Sul. In: LAMOSO, Lisandra Pereira (org.). Relações Internacionais de Mato Grosso do Sul: comércio, investimentos e fronteira. Curitiba: Íthala, 2016. Cap. 1. p. 15-31.

CAGED. Cadastro Geral de Empregados e Desempregados. Brasília, 2018. Disponível em: http://bi.mte.gov.br/bgcaged/caged perfil municipio/index.php. Acesso em: 26 mar. 2020

CHOLLEY, A. Observações sobre alguns pontos de vista geográficos. Boletim Geográfico, Rio de Janeiro, n. 180, p. 267-276, 1964.

CUNHA, R. C.; FARIAS, F. R. Dinâmica produtiva e ordenamento territorial dos agronegócios do Mato Grosso do Sul pós-2003. Geosul, Florianópolis, v. 34, n. 71, p. 130-153, 2019. https://doi.org/10.5007/1982-5153.2019v34n71p130

DELGADO, G. da C. Capital Financeiro e Agricultura no Brasil. São Paulo: Ícone Editora Ltda, 1985.

ESPÍNDOLA; C. J. CUNHA, R. C. C. A dinâmica geoeconômica recente da cadeia produtiva de soja no Brasil e no Mundo. Geotextos, v. 11, n. 1, p. 217-238, Salvador, UFBA, 2015. https://doi.org/10.9771/1984-5537geo.v11i1.12692

ESPÓSITO, T; CRUZ, K. K. C. da. Os resultados da parceria estratégica Brasil-China para o fortalecimento comercial da cadeia produtiva da soja no Mato Grosso do Sul 2003-2013. In: LAMOSO, L. P. (org.). Relações Internacionais de Mato Grosso do Sul: comércio, investimentos e fronteira. Curitiba: Íthala, 2016. p. 39-68. 
GIL, A. C. Métodos e técnicas de pesquisa social. Atlas: São Paulo, 1994.

GONÇALVES, J. S.; FONSECA, M. da G. D. Financiamento do Investimento da Agroindústria e Agropecuária: Análise de dois Planos Governamentais Recentes. In: Informações Econômicas. São Paulo, v, 25, n. 6, jun. 1995, p. 1-17. Disponível em:http://www.iea.sp.gov.br/ftpiea/ie/1995/tec30695.pdf. Acesso em: 23 mar. 2020

HAMADA, G. K. F. Investimento estrangeiro direto (IED) no Mato Grosso do Sul. In: LAMOSO, L. P. (org.). Relações Internacionais de Mato Grosso do Sul: comércio, investimentos e fronteira. Curitiba: Íthala, 2016. Cap. 3. p. 69-92.

IBGE. Instituto Brasileiro de Geografia e Estatística. Estimativa de População. Rio de Janeiro, 2019. Disponível em: https://sidra.ibge.gov.br/pesquisa/estimapop/tabelas. Acesso em: 23 mar. 2020.

Produto Interno Bruto dos Municípios. Rio de Janeiro, 2019. Disponível em: <https://sidra.ibge.gov.br/pesquisa/pib-munic/tabelas >. Acesso em: 21 mar. 2020.

Censo Agropecuário 2017. Rio de Janeiro, 2019d. Disponível em: https://sidra.ibge.gov.br/pesquisa/censo-agropecuario/censo-agropecuario-2017. Acesso em: 20 nov. 2020.

LAMOSO, Lisandra Pereira (org.). Relações Internacionais de Mato Grosso do Sul: comércio, investimentos e fronteira. Curitiba: Íthala, 2016. p. 39-68.

Comércio exterior e estruturas produtivas no Mato Grosso do Sul. Revista Geosul, v. 26, n. 51, 2011. https://doi.org/10.5007/2177-5230.2011v26n51p129

MAMIGONIAN, A. Notas Sobre os Frigoríficos do Brasil Central Pecuário. Boletim Paulista, São Paulo, p. 7-12, maio 1976.

MEIC. Ministério da Economia, Indústria e Comércio Exterior. Dados estatísticos do mercado externo. Brasília, 2019. Disponível em: http://comexstat.mdic.gov.br/pt/geral. Acesso em: 21 jan. 2020.

RANGEL, I. M. Ciclo Tecnologia e Crescimento. Rio de Janeiro: Civilização Brasileira, 1982.

SILVA, C. H. R. da; GOMES, T. N. Apontamentos sobre a política de incentivos fiscais e a industrialização de Mato Grosso do Sul. In: LAMOSO, L. P. (org.). Temas do desenvolvimento econômico brasileiro e suas articulações com o Mato Grosso do Sul. Curitiba: Íthala, 2016. Cap. 5. p. 159-190.

SEMADE. Secretaria de Estado de Meio Ambiente e Desenvolvimento Econômico. Diagnóstico Socioeconômico de Mato Grosso do Sul. Campo Grande: Semade MS, 2015. 134p.

. Planejamento Estratégico 2019 - 2024. Campo Grande: Semade MS, 2019.

SEMAGRO. Secretaria de Estado de Meio Ambiente, Desenvolvimento Econômico, Produção e Agricultura Familiar. Demanda mundial puxa exportações de minério de ferro do maciço de urucum. Campo Grande: Semagro MS, 2017.

Recebido em: 23/04/2020

Aceito para publicação em: 19/08/2020 